\title{
Carbohydrate deficient glycoprotein (CDG) syndrome type I
}

\author{
J Jaeken, G Matthijs, R Barone, H Carchon
}

CDG syndrome type I is a genetic, multisystemic disorder characterised by a partial deficiency of the $\mathrm{N}$-linked glycans of secretory glycoproteins, lysosomal enzymes, and probably also membranous glycoproteins. The first patients were reported in $1980 .^{1}$ The basic defect was elucidated only in 1995 as a phosphomannomutase deficiency. ${ }^{2}$ As of February 1996 some 200 patients worldwide (published and unpublished) were known to the authors. Since the N-linked glycoproteins play important roles in every organ and biochemical system of the body, it is no wonder that this syndrome is one of the most complex metabolic diseases known, with an extremely broad biochemical as well as clinical spectrum. ${ }^{3-6}$ (f Med Genet 1997;34:73-76)

Keywords: carbohydrate deficient glycoprotein syndrome.
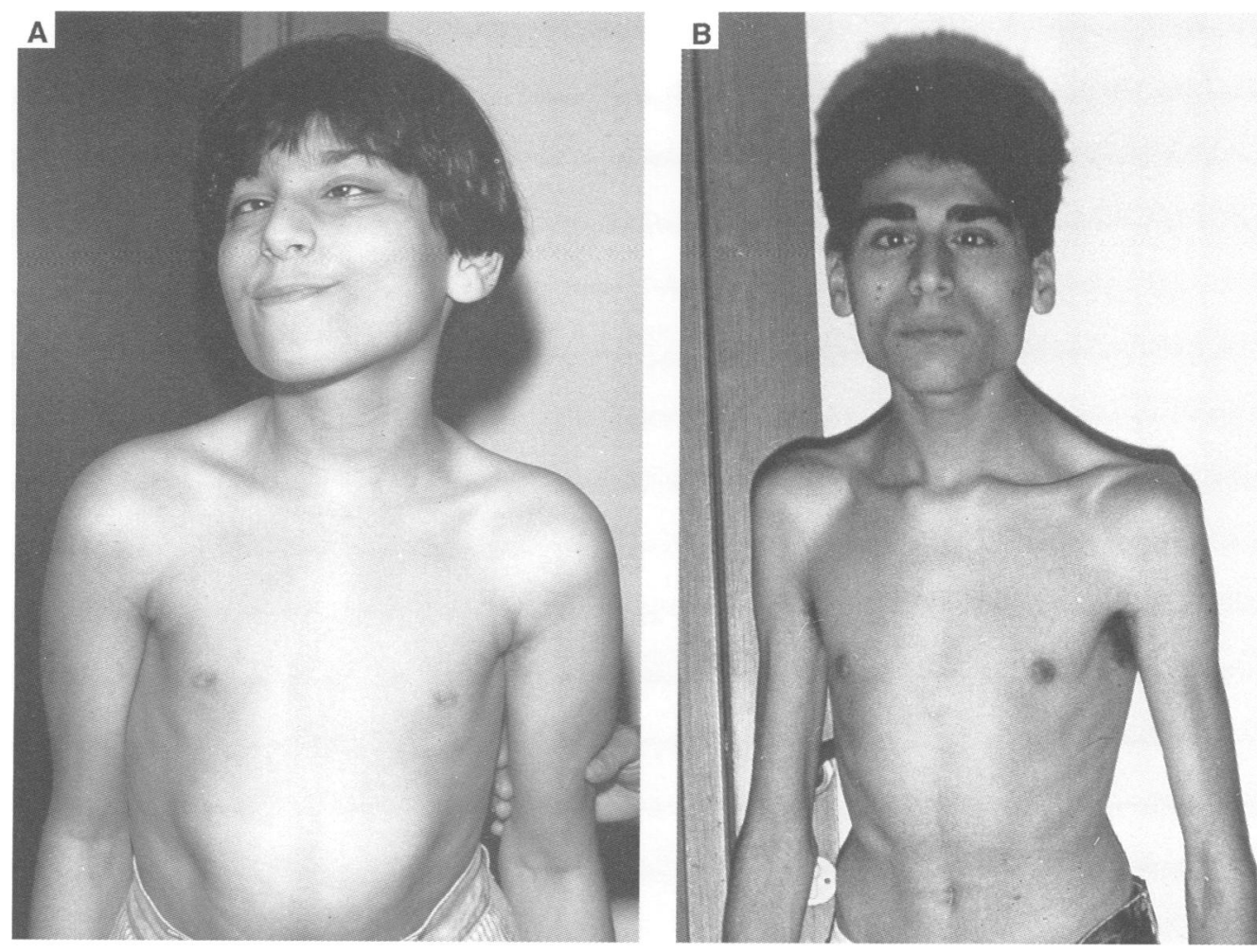

Figure 1 Sibs with CDG syndrome type I. (A) A girl aged 16 years; note strabismus and absence of breast development owing to hypogonadism. (B) Her brother aged 18 years.

\section{Clinical presentation}

For those familiar with the disease it can often be diagnosed in the first days of life. The nervous system is affected in the great majority of known patients and all other organs are involved in a variable way. The neurological picture comprises alternating internal strabismus, abnormal (roving) eye movements, axial hypotonia, psychomotor retardation (usually severe), ataxia, and often hyporeflexia. After infancy, as a rule there are retinitis pigmentosa, joint contractures, stroke-like episodes (in about $50 \%$ ), and sometimes epilepsy. Only rarely do these patients achieve walking without support, but there is no regression.

Other features are mild facial dysmorphism (fig 1), in particular large, somewhat dysplastic ears, abnormal subcutaneous adipose tissue distribution (fat pads, "orange peel" skin, "tal-

\author{
Department of \\ Paediatrics, University \\ Hospital Gasthuisberg, \\ Herestraat 49, B-3000 \\ Leuven, Belgium \\ J Jaeken \\ $\mathrm{H}$ Carchon \\ Centre for Human \\ Genetics, University of \\ Leuven, Leuven, \\ Belgium \\ G Matthijs \\ Department of \\ Paediatrics, University \\ of Catania, Catania, \\ Sicily \\ R Barone* \\ Correspondence to: \\ Dr Jaeken. \\ *Present address: Division of \\ Paediatric Neurology, \\ Institute of Paediatrics, \\ University of Catania, \\ Catania, Italy.
}



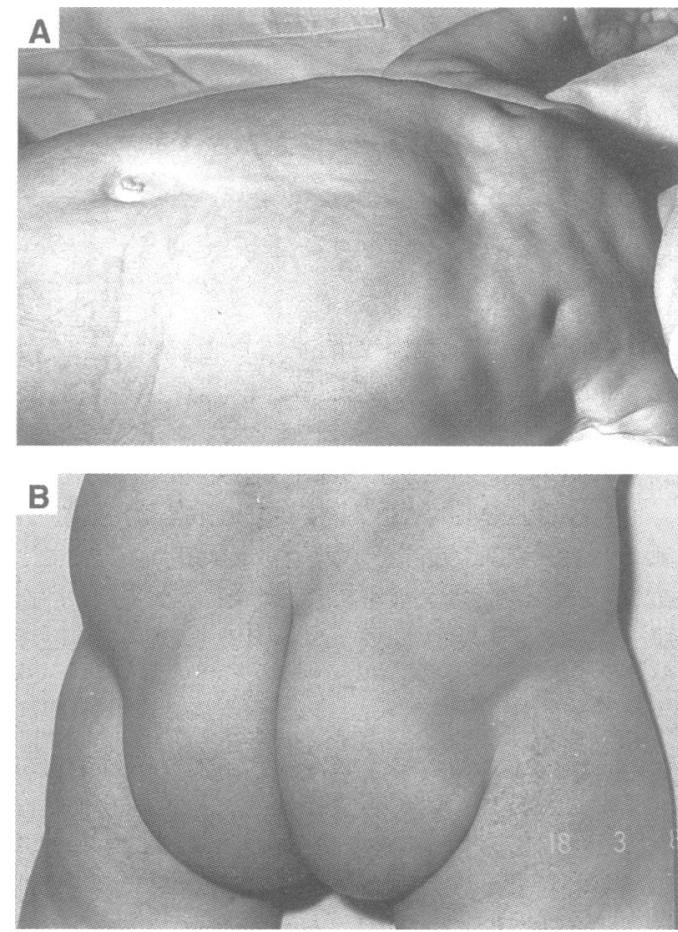

Figure 2 Typical features of CDG syndrome type I: $(A)$ inverted nipples, $(B)$ fat pads on the buttocks.

low") (fig 2), as well as dystrophic extremities, mild to moderate hepatomegaly, skeletal abnormalities, hypogonadism, and proteinuria. It is important to note that dysmorphism can be minimal. Some infants develop pericardial effusion or cardiomyopathy or both. The patients have often an extrovert and cheerful personality.
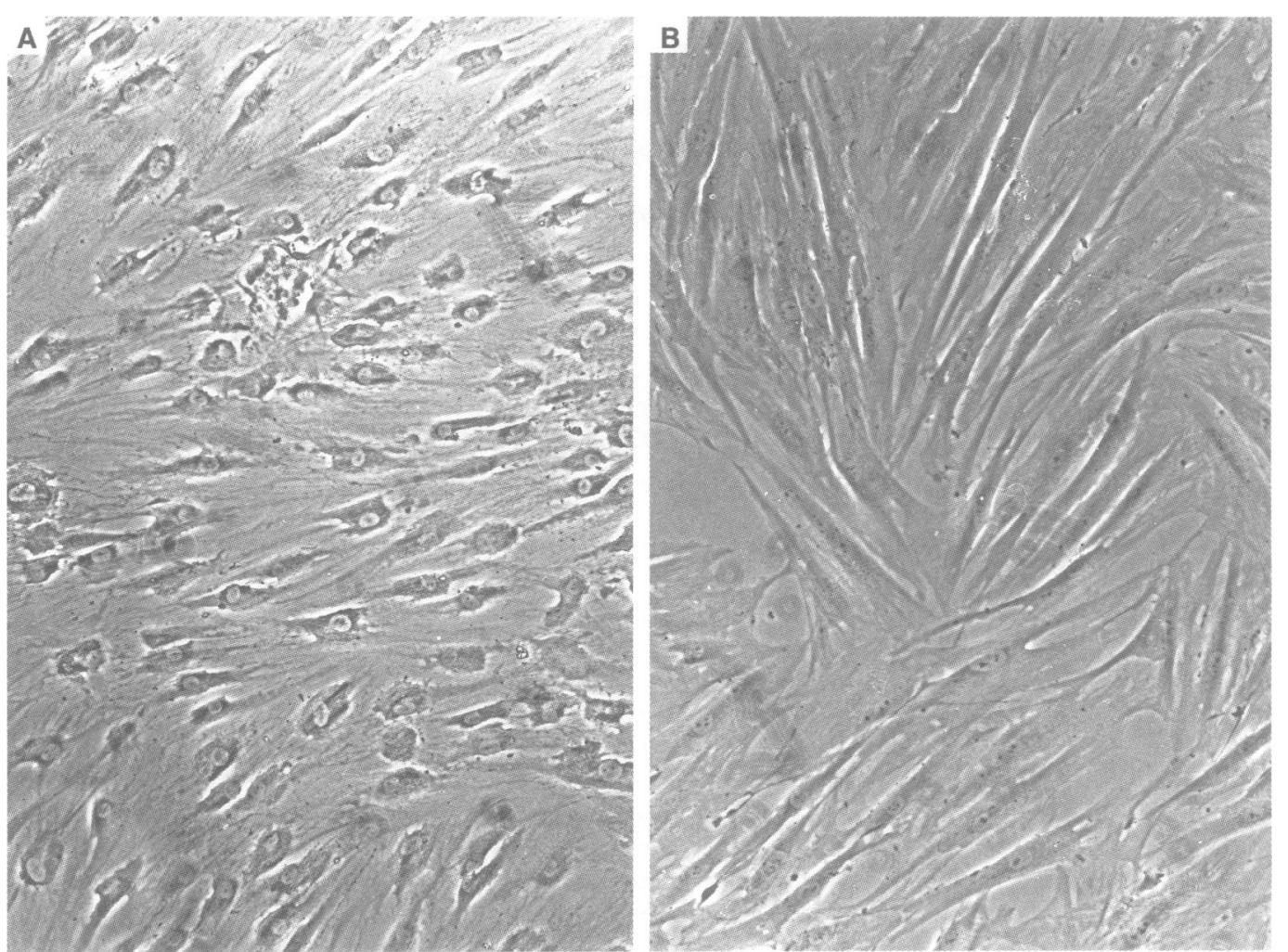

Biochemical features and basic defect

A large number of serum glycoproteins are abnormal including transport proteins, glycoprotein hormones, complement factors, lysosomal and other enzymes, enzyme inhibitors, and others. It was found that these patients have a unique coagulopathy (with a marked factor XI deficiency) ${ }^{10}$ as well as a new endocrinological entity. ${ }^{112}$ In general, the glycoprotein concentrations or enzyme activities in serum are decreased but some are increased (for example, follicle stimulating hormone, arylsulphatase A) and others are normal (for example, transferrin). Isoelectric focusing of these glycoproteins shows a cathodal shift. This is because of a partial deficiency of sialic acid, gliosis in the cerebral cortex, basal ganglia, and cysts, fibrosis of the testes, and lymph node mermalities. The peripheral nerves show dethe Schwann cells. The fibroblasts show signs 3), and dilated endoplasmic reticulum. Liver and glycogen storage, and electron microscop ows myelin-like and granular lysosomal inusions and dilated endoplasmic reticulum in the hepatocytes.

Figure 3 Cultured fibroblasts from patient with CDG syndrome type I showing $(A)$ features of premature aging (inclusions and ballooning) compared with control (B). 
a negatively charged sugar. Moreover, these patients have, to various extents, decreased serum levels of copper, iron, zinc, cholesterol, cortisol, total thyroxine $\left(\mathrm{T}_{4}\right)$, and tri-iodothyronine, most probably as a consequence of the decreased levels of transport proteins. Other non-glycoprotein abnormalities are hypoalbuminaemia and increased serum levels of growth hormone and insulin associated with normal or subnormal growth and mostly normal glycaemia. These endocrinological abnormalities are indicative of defects in receptors (membrane glycoproteins). In cultured skin fibroblasts, aberrant expression has been found of the genes for the small proteoglycans decorin and biglycan. ${ }^{13}$

The partial deficiency of sialic acid in serum transferrin was first reported in $1984 .{ }^{14}$ Subsequently galactose and $\mathrm{N}$-acetylglucosamine were also found to be deficient. ${ }^{1516}$ In 1992 and 1993 Japanese workers showed that the number of glycans on serum transferrin was decreased, pointing to a disturbance in the early steps of glycosylation, possibly in the formation of the dolicholpyrophosphate oligosaccharide precursor or in its transfer to the acceptor protein. ${ }^{1718}$ Hence a decreased incorporation was found of $\left[{ }^{3} \mathrm{H}\right]$ mannose into $\mathrm{N}$-linked oligosaccharides and their lipid precursors in fibroblasts of patients with CDG syndrome type I. ${ }^{1920}$ Finally, phosphomannomutase deficiency was shown to be the major cause of the CDG syndrome type $\mathrm{I}^{2}$ (unpublished observations). Phosphomannomutase converts mannose-6-phosphate into mannose-1-phosphate, which is then converted to GDP-mannose. This compound is the donor of the nine mannose units needed for the synthesis of the dolicholpyrophosphate oligosaccharide in the endoplasmic reticulum. Phosphomannomutase has been well characterised in yeast where it is encoded by the SEC53 gene. It is a protein that acts as a dimer and shows phosphomannomutase activity in yeast and $E$ coli. ${ }^{21}$ No published reports are available on phosphomannomutase activity in man. Efforts to clone and map the human homologue of SEC53 are under way.

\section{Diagnosis}

CDG syndrome type I should be considered in any unexplained neurological syndrome including psychomotor retardation and, in infancy, axial hypotonia, particularly when associated with various combinations of the above mentioned clinical and biochemical abnormalities. Particularly suggestive are unexplained feeding problems with failure to thrive, abnormal subcutaneous fat distribution, retracted nipples, unexplained liver fibrosis, and decreased coagulation factor XI and antithrombin III. However, as said above, dysmorphic features may be minimal and it seems that even significant encephalopathy may be absent. Some patients have received a diagnosis of leprechaunism, lipodystrophy, Smith-LemliOpitz syndrome, a peroxisomal disorder, or Marfan syndrome. Owing to the partial thyroxine binding globulin deficiency, some of these patients can be detected through neonatal screening for congenital hypothyroidism with $\mathrm{T}_{4}$ measurement.

The diagnosis of CDG syndrome type $\mathrm{I}$ is usually made by isoelectric focusing and immunofixation of serum transferrin. Normal serum transferrin is mainly composed of tetrasialotransferrin besides small amounts of mono-, di, tri-, penta-, and hexasialotransferrin. The partial deficiency of sialic acid in CDG syndrome type I causes a cathodal shift resulting in a marked increase of both asialo- and disialotransferrin, and a decrease of tetra-, penta-, and hexasialotransferrin. These changes can be measured by densitometry. The carbohydrate deficient transferrin (CDT) assay enables the quantification of the total sialic acid deficient serum transferrin. ${ }^{22}$ It should be noted that similar transferrin changes are found in chronic alcoholism, ${ }^{23}$ galactosaemia, ${ }^{24-26}$ and fructosaemia. ${ }^{27}$

The diagnosis is confirmed by finding decreased phosphomannomutase activity in leucocytes, fibroblasts, or liver. Heterozygote detection is now possible as well as prenatal diagnosis, since the enzyme is active in amniocytes. ${ }^{2}$ Remarkably, in the fetus with CDG syndrome type I, transferrin isoelectric focusing and other tests used for the detection of the glycosylation defect show normal results. ${ }^{28}$

Three other CDG syndrome types have been reported each in only two families: type II resulting from a Golgi localised $\mathrm{N}$-acetylglucosaminyltransferase II deficiency, ${ }^{29}$ and types III $^{30}$ and IV $^{31}$ with an unknown basic defect. All three show a cathodal shift on serum transferrin isoelectric focusing different from type I.

\section{Genetics}

CDG syndrome type I is inherited in an autosomal recessive mode. The CDG syndrome type I locus has recently been mapped by Martinsson et $a l^{\beta 2}$ to chromosome $16 \mathrm{p}$, to a $13 \mathrm{cM}$ interval between markers D16S406 and S16S500.

We have analysed this region in 17 families of Belgian, Dutch, French, German, Canadian, and Italian origin. Linkage to the region between D16S406 and S16S500 was confirmed in 10 of 11 informative families. In one family with two affected sibs, the disease was not linked to chromosome $16 \mathrm{p} .^{33}$

1 Jaeken J, Vanderschueren-Lodeweyckx $\mathbf{M}$, Casaer $\mathrm{P}$, et al. Familial psychomotor retardation with markedly fluctuating serum proteins, FSH and GH levels, partial TBG deficiency, increased serum arylsulphatase $A$ and increased CSF protein: a new syndrome? Pediatr Res 1980;14:179.

2 Van Schaftingen E, Jaeken J. Phosphomannomutase deficiency is a cause of carbohydrate-deficient glycoprotein syndrome type I. FEBS Lett 1995;377:318-20.

3 Jaeken J, Stibler H, Hagberg B. The carbohydrate-deficient glycoprotein syndrome: a new inherited multisystemic disease with severe nervous system involvement. Acta Paediatr Scand Suppl 1991;375:monograph.

4 Jaeken J, Carchon H. The carbohydrate-deficient glycoprotein syndromes: an overview. $\mathcal{f}$ Inherited Metabol Dis 1993;16:813-20

5 Jaeken J, Carchon H, Stibler H. The carbohydrate-deficient glycoprotein syndromes: pre-Golgi and Golgi disorders? Glycobiology 1993;3:423-8.

6 Stibler H, Blennow G, Kristiansson B, Lindehammer H, Hagberg B. Carbohydrate-deficient glycoprotein syndrome: clinical expression in adults with a new metabolic disease. $\mathcal{F}$ Neurol Neurosurg Psychiatry 1994;57:552-6. 
7 van der Knaap MS, Wevers RA, van Wiik A, Jakobs C. Finnish type nephrotic syndrome: an unknown phenotype of carbohydrate deficient glycoprotein syndrome. Abstracts of the 32nd SSIEM annual symposiun
Academic Publishers, 1994:207.

8 Hutchesson ACJ, Gray RGF, Spencer DA, Keir G. Carbohydrate deficient glycoprotein syndrome; multiple abnormalities and diagnostic delay. Arch Dis Child 1995;72 445-6.

9 Eyskens F, Ceuterick C, Martin JJ, Janssens G, Jaeken J. Carbohydrate-deficient viously unreported features. Acta Paediatr 1994;83:892-6.

10 Van Geet C, Jaeken J. A unique pattern of coagulation abnormalities in carbohydrate-deficient glycoprotein syndrome. Pediatr Res 1993;33:540-1.

11 de Zegher F, Jaeken J. Endocrinology of the carbohydratedeficient glycoprotein syndrome type 1 from birth through adolescence. Pediatr Res 1995;37:395-401.

12 Kristiansson B, Stibler H, Wide L. Gonadal function and glycoprotein hormones in the carbohydrate-deficient gly60.

$13 \mathrm{Gu} \mathrm{J}$, Wada Y. Aberrant expressions of decorin and biglycan genes in the carbohydrate-deficient glycoprotein syngenes in the carbohydrate-deficient

14 Jaeken J, van Eijk HG, van der Heul C, Corbeel L, Eeckels $R$, Eggermont E. Sialic acid-deficient serum and cerebro-
spinal fluid transferrin in a newly recognized genetic synspinal fluid transferrin in a newly recognize

15 Jaeken J, Eggermont E, Stibler H. An apparent homozygous $\mathrm{X}$-linked disorder with carbohydrate deficient serum glycoproteins. Lancet 1987;3:1398.

16 Stibler $\mathrm{H}$, Jaeken J. Carbohydrate deficient serum transferrin in a new systemic hereditary syndrome. Arch Dis Child 1990;65:107-11.

17 Wada Y, Nishikawa A, Okamoto N, et al. Structure of serum transferrin in carbohydrate-deficient glycoprotein syndrome. Biochem Biophys Res Commun 1992;189:832-6.

18 Yamashita $\mathrm{K}$, Ideo $\mathrm{H}$, Ohkura $\mathrm{T}$, et al. Sugar chains of serum transferrin from patients with carbohydrate de-
ficient glycoprotein syndrome. F Biol Chem 1993;268: 5783-9.

19 Powell LD, Paneerselvam K, Vij R, et al. Carbohydratedeficient glycoprotein syndrome: not an $\mathrm{N}$-linked oligosaccharide processing defect, but an abnormality in lipid-linked oligosaccharide biosynthesis? $\mathcal{f}$ Clin Invest 1994;94:1901-9.

20 Panneerselvam K, Freeze HH. Enzymes involved in the synthesis of mannose-6-phosphate from glucose are nor$\mathrm{mal}$ in carbohydrate deficient glycoprotein syndrome fibroblasts. Biochem Biophys Res Commun 1995;208:51722.

21 Kepes F, Scheckman R. The yeast SEC53 gene encode phosphomannomutase. f Biol Chem 1988;263:9155-61. 2 Stibler $\mathrm{H}$, Borg S, Joustra $M$. A modified method fo the assay of carbohydrate-deficient transferrin (CDT) in serum. Alcohol Alcoholism 1989;24:388.

23 Stibler H, Borg S, Joustra M. Micro anion exchang chromatography of carbohydrate-deficient transferrin in serum in relation to alcohol consumption. Alcoholism Clin $\operatorname{Exp} \operatorname{Res} 1986 ; 10: 535-44$.

24 Spaapen LJM, Vulsma T, Theunissen PMVM, van der Meer SB, Jaeken J. Galactosaemia, a carbohydrate-deficien glycoprotein syndrome. Abstracts of the 30th SSIEM annual meeting. Lancaster: Kluwer Academic Publishers, 1992. 10.

25 Jaeken J, Kint J, Spaapen L. Serum lysosomal enzyme abnormalities in galactosaemia. Lancet 1992;340:1472-3. 26 Besley GTN, Bridge C, Marsh LM, Wraith JE, Walter JH. Two new cases of generalized UDP-galactose-4-epimerase deficiency: abnormal transferrin patterns at presentation. Abstracts of the 33rd SSIEM annual symposium. Lancaster: Kluwer Academic Publishers, 1995:160.

27 Adamowicz M, Pronicka E. Carbohydrate deficient glycoprotein syndrome-like transferrin isoelectric focusin pattern in untreated fructosaemia. Eur F Pediatr 1996;155: 347-8.

28 Clayton P, Winchester B, Di Tomaso E, Young E, Keir G Rodeck C. Carbohydrate-deficient glycoprotein syndrome: normal glycosylation in the fetus. Lancet 1993; 341:956.

29 Jaeken J, Schachter $H$, Carchon $H$, De Cock P, Coddeville B, Spik G. Carbohydrate deficient glycoprotein syndrome type II: a deficiency in Golgi localised N-acetyl-glucosaminyltransferase II. Arch Dis Child 1994;71:123-7.

30 Stibler H, Westerberg B, Hanefeld F, Hagberg B. Carbohydrate-deficient glycoprotein (CDG) syndrome-a new variant, type III. Neuropediatrics 1993;24:51-2.

31 Stibler H, Stephani U, Kutsch U. Carbohydrate-deficien glycoprotein syndrome-a fourth subtype. Neuropediatrics 1995;26:235-7.

32 Martinsson T, Bursell C, Stibler H, et al. Linkage of a locus for carbohydrate-deficient glycoprotein syndrome type I (CDG1) to chromosome $16 \mathrm{p}$, and linkage disequilibrium to microsatellite marker D16S406. Hum Mol Genet 1994; 3:2037-42.

33 Matthijs G, Legius E, Schollen E, et al. Evidence for genetic heterogeneity in the carbohydrate-deficient glycoprotein syndrome type I (CDG1). Genomics 1996;35:597-9. 